DOI: https://doi.org/10.24127/ajpm.v10i2.3430

\title{
BERPIKIR MATEMATIS RIGOR: KONTRIBUSI PADA PENGEMBANGAN PENGETAHUAN METAKOGNITIF-SELF ASSESSMENT MAHASISWA
}

\author{
Siska Firmasari ${ }^{*}$, Dadang Juandi ${ }^{2}$ \\ ${ }^{1 *}$ Universitas Swadaya Gunung Jati, Cirebon, Indonesia \\ ${ }^{2}$ Universitas Pendidikan Indonesia, Bandung, Indonesia \\ *Corresponding author. Universitas Swadaya Gunung Jati, Cirebon, Indonesia. \\ E-mail: $\quad$ siska.firmasari@upi.edu ${ }^{1 *}$ \\ dadang.juandi@upi.edu $^{2}$
}

Received 26 December 2020; Received in revised form 14 June 2021; Accepted 06 July 2021

\begin{abstract}
Abstrak
Penelitian bertujuan untuk menganalisis berpikir matematis rigor mahasiswa dari tiga level struktur fungsi kognitif yang dihubungkan dengan kontribusinya terhadap pengetahuan metakognitif self-assessment pada perkuliahan Sistem Bilangan Real. Penelitian ini merupakan penelitian kualitatif dengan jenis studi kasus. Subjek penelitian yaitu mahasiswa Program Studi Pendidikan Matematika berjumlah tiga orang yang mengontrak mata kuliah Sistem Bilangan Real. Subjek penelitian dipilih berdasarkan hasil tes yang mengategorikan mahasiswa dalam tiga level struktur fungsi kognitif berpikir matematis Rigor. Hasil penelitian ini menunjukkan bahwa berpikir matematis Rigor memiliki kontribusi pada pengetahuan metakognitif self-assessment mahasiswa. Level berpikir matematis Rigor mampu menggiring ketelitian, ketekunan intelektual, penyelidikan kritis, dan pencarian kebenaran dalam menyelesaikan permasalahan secara tepat dan sistematis menjadi sebuah pengalaman pembelajaran yang dijelaskan sebagai metakognitif. Mahasiswa pada level berpikir relasional abstrak mampu menilai kemampuan diri sendiri dengan sangat baik, belajar secara mandiri, dan mampu memilih dengan pasti cara penyelesaian masalah melalui penempatan metode yang tepat. Mahasiswa dengan level berpikir kuantitatif mampu menyelesaikan permasalahan dengan kemampuan mengatur strategi sesuai tujuan pembelajaran melalui diskusi dengan rekan sebaya. Mahasiswa level berpikir kualitatif lebih fokus pada simbol, dan merepresentasikan pengetahuannya melalui visualisasi. Mereka lebih menyukai tipe penyelesaian permasalahan evaluasi dengan cara mengubah kalimat panjang menjadi simbol matematika yang jelas.
\end{abstract}

Kata kunci: Berpikir Matematis Rigor, Metakognitif, Self-Assessment.

\begin{abstract}
This study aims to analyze students' rigorous mathematical thinking from three levels of cognitive function structure associated with their contribution to self-assessment metacognitive knowledge in Real Number System lectures. This research is qualitative research with a type of case study. The research subjects were three students of the Mathematics Education Study Program who contracted the Real Number System course. Selecting research subjects based on test results identifies students into three rigorous mathematical thinking cognitive function structures. This study's results indicate that rigorous mathematical thinking contributes to students' self-assessment metacognitive knowledge. Rigour's mathematical thinking level can lead to thoroughness, intellectual persistence, critical investigation, and truth-seeking in solving problems appropriately and systematically into a learning experience described as metacognitive. Students at the level of abstract relational thinking can assess their abilities very well, learn independently, and choose with certainty how to solve problems by using appropriate methods. Students with a quantitative thinking level can solve problems with the ability to set strategies according to learning objectives through discussions with peers. Qualitative thinking level students focus more on symbols, represent their knowledge through visualization, and evaluate problem-solving by changing long sentences into clear mathematical symbols.
\end{abstract}

Keywords: Metacognitif, Rigorous Mathematical Thinking, Self-Assessment

This is an open access article under the Creative Commons Attribution 4.0 International License 
DOI: https://doi.org/10.24127/ajpm.v10i2.3430

\section{PENDAHULUAN}

Paradigma berpikir matematis rigor menekankan pada perubahan struktur kognitif anak yang harus relevan dengan tiga aspek yaitu struktur, kognitif, dan perubahan (Kinard, 2006; Kinard \& Kozulin, 2008). Perubahan struktur kognitif merupakan perubahan pada diri siswa dari kondisi awal ke kondisi yang diinginkan, perlu jangka waktu sehingga hasilnya akurat (Ifenthaler et al., 2011). Perubahan struktur kognitif ini memainkan peranan penting dalam pembelajaran, karena menampilkan keseluruhan proses dan intervensi yang lebih efektif oleh guru atau oleh siswa itu sendiri, sehingga mengarah pada hasil yang lebih baik (Catarreira et al., 2017; Wilkerson-Jerde \& Wilensky, 2011). Secara teori, berpikir matematis rigor memiliki tiga level struktur kognitif yaitu berpikir kualitatif (mampu menggunakan berbagai sumber informasi), berpikir kuantitatif (mampu mengukur hubungan spasial secara tepat), and berpikir relasional abstrak (Kinard \& Kozulin, 2015).

Perubahan struktur kognitif dalam pembelajaran matematika merupakan bentuk mengkonstruksi pengetahuan baru berdasarkan kemampuan pemrosesan informasi siswa yang melibatkan beberapa konsep matematika (Navaneedhan \& Kamalanabhan, 2017). Para pakar konstruktivis menyarankan untuk memulai dengan pengalaman sehari-hari para siswa, kemudian berusaha untuk merekonstruksi sebuah pengetahuan baru (Siahaan, 2017). Rigorous mathematical thinking atau berpikir matematis Rigor memiliki perbedaan dengan pendekatan konstruktivis populer saat ini, karena lebih menekankan pada memulai sebuah konstruksi pengetahuan dari materi matematika kemudian menerapkan metode, bahasa dan karakteristik operasi dari subjek matematika untuk pengalaman sehari-hari siswa.

Untuk mengembangkan berpikir matematis rigor siswa, guru dapat melakukan dengan cara mengkomuni- kasikan melalui pertanyaan yang mendorong siswa untuk menjelaskan bagaimana mereka memperoleh jawaban mereka dengan mendeskripsikan proses berpikir mereka, membuat solusi baru, memodifikasi solusi yang ada dan menyajikan solusi yang bervariasi (Magsalay et al., 2019). Siswa harus mampu mengembangkan berbagai kemampuan diri terkait pemahaman materi matematika dan bagaimana mereka membangun pengetahuan baru dari merefleksikan berbagai hal yang mereka ketahui menjadi point-point penting dalam belajar (Colognesi et al., 2020; Veenman, 2012). Keinginan yang kuat dari diri siswa untuk belajar, memiliki percaya diri dalam membangun kualitas pemikiran, dan akhirnya mampu mencapai tingkat abstraksi dari level berpikir matematis rigor. Keseluruhan hal tersebut mampu menjelaskan metakognitif siswa.

Metakognitif merupakan suatu pengetahuan atau kemampuan yang dimiliki seseorang dalam mengelola dan mengendalikan dinamika kognitifnya yang dapat mempengaruhi cara belajar secara efektif (Adadan \& Oner, 2018). Metakognitif dapat diartikan juga memikirkan pemikiran sendiri (Hsu et al., 2016; Jaleel \& P., 2016). Terdapat dua pengetahuan metakognitif yaitu metakognitif self-management dan metakognitif self-assessment (Rivers, 2001). Metakognitif self-management adalah kemampuan untuk mengelola perkembangan kognitif diri sendiri lebih lanjut, sedangkan metakognitif self-assessment adalah kemampuan untuk menilai kualitas pekerjaan diri sendiri dimana siswa belajar untuk memeriksa respon mereka sendiri dan menjadi sadar akan kesalahan atau jawaban yang tidak masuk akal (Nbina \& Viko, 2010; Nuhfer et al., 2016). Metakognitif selfassessment merupakan kombinasi dari tiga kompenen penting yang terhubung dalam sebuah siklus, yaitu self-monitoring, selfjudgement, serta learning targets and instructional correctives sesuai kebutuhan. 
DOI: https://doi.org/10.24127/ajpm.v10i2.3430

Pengetahuan makna metakognitif
dalam
pemberikan kelajaran, karena pengetahuan
metakognitif menunjang keberhasilan
pembelajaran siswa (Sukiyanto, 2020).
Pada pembelajaran matematika, seorang
siswa dapat membangun pengetahuan
dalam pikirannya berdasarkan suatu
konsep dengan pedagogik tingkat tinggi
(Prabowo \& Juandi, 2020).

Keseimbangan unsur-unsur yang terkait dalam pembelajaran, pedagogik guru, dan rancangan pembelajaran yang sesuai mendukung berkembangnya kemampuan siswa baik pada faktor kognitifnya maupun metakognitif siswa.

Hasil penelitian Purwaningsih (2017) menyatakan bahwa terdapat hubungan yang positif dan signifikan antara pengetahuan metakognitif dengan kemampuan kognitif mahasiswa. Kemampuan kognitif tingkat tinggi yang dicapai mahasiswa pada level berpikir matematis rigor, membawa fungsi kognitifnya memiliki tiga komponen penting yaitu komponen konseptual, tindakan, dan motivasi (Kinard, 2006). Ketiga komponen fungsi kognitif ini memiliki peran diluar pengetahuan matematika namun bersifat mengevaluasi apa yang telah dicapai mahasiswa (metakognitif selfassessment). Sehingga dapat ditarik hubungan antara berpikir matematis rigor dan pengetahuan metakognitifnya.

Tiga level fungsi kognitif dari berpikir matematis rigor dapat digunakan untuk mengidentifikasi penyelesaian permasalahan matematika siswa (Syahputri \& Fitriyani, 2019; Fitriyani, 2016). Sementara penelitian mengenai metakognitif yang dilakukan oleh Syafa'ah dan Handayani (2015), menunjukkan bahwa instrumen metakognitif self-assessment dapat digunakan untuk mengukur pengetahuan berpikir evaluasi yang dimiliki mahasiswa. Sedangkan sebuah penelitian dari Hostetler,
Luo, dan Stefaniak (2018) menunjukkan bahwa metakognitif self-assessment menjadi salah satu alat ukur yang akurat untuk mengukur kompetensi mahasiswa. Namun sampai sejauh ini belum ada penelitian yang memfokuskan pada hubungan berpikir matematis rigor dan metakognitif selfassessment., sehingga disusunlah sebuah penelitian terkait hubungan keduanya.

Penelitian ini bertujuan untuk menganalisis berpikir matematis rigor mahasiswa dari tiga level struktur fungsi kognitif dihubungkan dengan kontribusinya terhadap pengetahuan metakognitif selfassessment pada perkuliahan Sistem Bilangan Real. Hasil dari penelitian akan dijadikan dasar untuk self-management, agar mahasiswa paham mengenai dirinya dan apa yang harus dia lakukan untuk belajar.

\section{METODE PENELITIAN}

Penelitian menggunakan metode kualitatif dengan jenis studi kasus, karena penelitian ini mengadakan pengumpulan data yang mendalam melibatkan berbagai sumber informasi dan melaporkan deskripsi kasus (Alpi \& Evans, 2019; Cresswell \& Speelman, 2020). Penelitian dilaksanakan pada tahun akademik 2020/2021 semester ganjil perkuliahan Analsisi Real. Penelitian akan memfokuskan pada proses belajar mahasiswa materi sistem bilangan real pada tiga level fungsi kognitif dari berpikir matematis rigor yang dihubungkan dengan metakognitif self-assessment. Mahasiswa yang mengontrak mata kuliah Analisis Real sebanyak tiga orang menjadi subjek penelitian. Penentuan subjek penelitian berdasarkan hasil tes yang dilakukan sebelumnya untuk satu kelas, kemudian dipilih masing-masing satu orang yang mewakili masing-masing level fungsi kognitif untuk berpikir matematis rigor.

Instrumen penelitian berupa soal tes uraian materi sistem bilangan real, kuesioner yang merepresentasikan metakognitif selfassessment mahasiswa, dan wawancara. 
Penelitian dimulai dengan mengumpulkan tiga orang subjek penelitian kemudian diberikan soal uraian materi bilangan real. Kemudian mahasiswa mengisi kuesioner sebanyak dua puluh item pernyataan yang mencerminkan metakognitif self-assessment mereka selama belajar sistem bilangan real, kemudian mencari hubungan antara level berpikir matematis rigor dan bagaimana mahasiswa menilai kemampuan diri mereka sendiri. Untuk menekankan hasil yang ada, wawancara dilakukan secara online melalui media zoom dengan mahasiswa.

Kemudian wawancara terhadap ketiga subjek dilakukan berdasarkan butir-butir kuesioner yang telah diisi mahasiswa, pertanyaan dibuat lebih mendalam, sehingga evaluasi terhadap diri mereka masing-masing terlihat lebih jelas, bagaimana mereka belajar meyakinkan bahwa diri mereka mampu belajar Sistem Bilangan Real dengan berbagai permasalahan yang dialami dan metode belajar yang sesuai dengan diri mereka masing-masing.

\section{HASIL DAN PEMBAHASAN}

Berdasarkan hasil tes materi Sistem Bilangan Real berbentuk soal uraian yang dikerjakan oleh mahasiswa, terdapat berbagai perbedaan yang menjurus kepada kemampuan kognitif masing-masing mahasiswa. Soal yang diberikan mampu menggambarkan setiap level fungsi kognitif berpikir matematis rigor mahasiswa, karena soal tersebut disusun dengan menginginkan jawaban yang menghubungkan beberapa teori saling terkait dengan materi Sistem Bilangan Real, pemahaman materi melalui metode pembuktian, serta kemampuan mahasiswa dalam merekonstruksi jawaban. Mahasiswa juga memperlihatkan cara yang berbeda dalam menyuguhkan pola pikir mereka dalam bentuk rangkaian jawaban sampai memberikan kesimpulan dengan bahasa yang sesuai dengan pengalaman mereka.

Mahasiswa yang mampu menggunakan semua struktur fungsi kognitif dari RMT level berpikir relasional abstrak, dapat menemukan ide awal dari penyelesaian permasalahan yang diberikan dimana salah satu idenya dengan menggunakan kontradiksi dari variabel $y$ yang awalnya anggota bilangan rasional dan mampu mengaktifkan pengetahuan sebelumnya dengan cara menghubungkan dan menyelesaikan aspek-aspek yang dipikirkan, terlihat dari jawaban diatas mahasiswa menghubungkan dengan konsep bilangan rasional dan operasi aljabar pada bilangan rasional. Dia jelas dalam penguatan jawaban secara logis sehingga bagi yang melihat hasil jawaban tersebut tidak menghasilkan penafsiran berbeda, prosedur jawaban sistematis, dan mampu melibatkan definisi dan teorema dalam pembuktian dalam perkalian bilangan rasional dan irasional yang menghasilkan bilangan irasional.

Sedangkan hasil tes dari mahasiswa yang memiliki struktur fungsi kognitif berpikir matematis rigor level berpikir kuantitatif dengan ketelitian, menunjukkan adanya kemampuan mahasiswa dalam menggunakan kontradiksi untuk pembuktian menggunakan analisis disesuaikan dengan pengertian bilangan rasional dan irrasional, mampu menerapkan dan cukup baik dalam menghubungkan antar konsep bilangan rasional dan irrasional yang berkaitan dengan proses operasi penjumlahan dan perkalian bilangan, serta diakhir mampu menyimpulkan jawaban sesuai dengan pertanyaan soal walaupun terlihat sederhana. Ia mampu juga untuk 
mengembangkan jawaban dari contohcontoh yang diberikan pengajar pada materi sistem bilangan real, dan menggunakan bahasa sendiri untuk menyampaikan jawabannya.

Untuk mahasiswa yang memiliki struktur fungsi kognitif RMT level berpikir kualitatif, dia cukup cakap dalam menuliskan simbol bilangan rasional, bilangan irrasional, dan bilangan bulat; paham kaitan materi antara pengertian dan operasi aljabar untuk bilangan rasional; mampu mencari informasi lalu mengumpulkan diakhiri dengan melengkapi informasi yang diperlukan untuk menjawab soal pembuktian perkalian dua bilangan rasional dan irrasional menjadi bilangan irrasional walaupun belum cakap dalam menginterpretasikan simbol bilangan irrasional; serta mampu membangun sebuah hipotesis sederhana dengan didasarkan pada hubungan antar operasi aljabar bilangan rasional. Dia mampu untuk membaca maksud soal yang diberikan kemudian menghubungkan dengan teori-teori yang memiliki kaitan langsung dengan jawaban.

Struktur fungsi kognitif yang tercermin dari ketiga subjek penelitian sesuai dengan konsep yang dijelaskan Vygotsky, dimana fungsi kognitif yang terbentuk merupakan transformasi dari hubungan spontanitas pengalaman sehari-hari mahasiswa dengan konsep operasional pengetahuan mereka (Kinard \& Kozulin, 2008). Sebelum mencapai tingkat kognitif pada level relasional abstrak atau memiliki kemampuan penalaran konseptual yang ketat, biasanya pengolahan kognitif siswa didominasi oleh fungsi kognitif alami. Interaksi mereka didominasi oleh pengalaman dalam kehidupan sehari-hari, serta objek dan pengetahuan yang telah dikenal sebelumnya. Kemudian dengan pemberian dan penyampaian materi yang terstuktur, sistematis, dan ketat, maka struktur fungsi kognitif ini akan membentuk level-level berpikir yang membedakan cara penerimaan siswa terhadap materi-materi yang disampaikan oleh pengajar. Untuk memperoleh kesimpulan dari ketiga level berpikir matematis yang ketat ini, pengajar harus melakukan serangkaian pemberian tugas yang berfokus pada perbandingan pemahaman konseptual mahasiswa.

Ketiga mahasiswa yang dijadikan subjek penelitian mewakili masing-masing fungsi kognitif berpikir matematis rigor, menunjukkan keinginan yang kuat untuk belajar, memiliki rasa percaya diri dalam membangun pemikiran dalam merekonstruksi pengetahuannya, sampai mencapai kemampuan abstraksi level tinggi. Kesemua aspek tersebut yang mampu menjelaskan secara detail pengetahuan metakognitif self-assessment mahasiswa pada materi sistem bilangan real. Untuk mengetahuinya maka pengetahuan metakognitif self-assessment terbagi dalam tiga komponen pada satu siklus yang diinterpretasikan melalui kuesioner online yang telah disebar kepada ketiga mahasiswa, lalu dilakukan wawancara secara langsung untuk mempertajam jawaban dari kuesioner yang telah mereka isi.

Ketiga subjek penelitian yang diminta untuk mengisi kuesioner diberikan arahan bahwa pengisian harus sesuai dengan yang mereka alami sehingga tampak kejujuran dalam pembelajaran yang mereka lakukan dan mereka paham terhadap diri mereka masing-masing. Subjek harus memahami diri mereka masing-masing dan mengingat berbagai pengalaman yang telah mereka lalui selama pembelajaran. Karena melalui pengalaman selama pembelajaran, mahasiswa dapat merekonstruksi pengetahuannya sendiri (Sholihah \& Mahmudi, 2015), dan melibatkan kemampuan secara psikologis untuk mengevaluasi diri. Hal ini berpengaruh pada kecenderungan subjek untuk mengenali diri pribadi. Pada Tabel 1 diperlihatkan pengetahuan metakognitif self-assessment mahasiswa. 
DOI: https://doi.org/10.24127/ajpm.v10i2.3430

Tabel 1. Pengetahuan Metakognitif Self-assessment Mahasiswa

\begin{tabular}{ccl}
\hline No & \multicolumn{1}{c}{ Komponen } & \multicolumn{1}{c}{ Indikator } \\
\hline 1. & Self-Monitoring & Mampu melakukan evaluasi diri \\
& & Mampu mengimplementasikan strategi \\
& & Mampu melakukan upaya untuk menyesuaikan strategi \\
& & yang digunakan dengan hasilnya. \\
2. & Self-Judgement & Mampu menghubungkan tindakan dengan hasil \\
& & Mampu menyalahkan orang lain \\
3. & Learning Targets and & Mampu mencari umpan balik \\
& Instructional Correctives & Mampu meningkatkan kebenaran dari jawaban. \\
& & Mengoreksi kesalahpahaman \\
& & Memperluas pengetahuan. \\
\hline
\end{tabular}

(Chang, 2010; Griffin, 2019; Hearn \& McMillan, 2008)

Mahasiswa dengan level berpikir relasional abstrak, yang telah mencapai level kemampuan berpikir abstrak tingkat tinggi, berdasarkan hasil kuesioner dan wawancara secara mendalam satu persatu untuk semua level fungsi kognitif, terlihat sangat baik memenuhi tiga komponen metakognitif selfassessment. Untuk self-monitoring, terlihat bahwa dia menunjukkan kesadaran dalam berpikir dan merekonstruksi berbagai pengetahuan yang dia terima sebagai bentuk evaluasi diri. Kesadaran dalam berpikir terkadang membuatnya lama dalam menyelesaikan sebuah permasalahan, karena menurutnya, harus memikirkan solusi yang tepat sehingga alur jawaban menjadi konsisten sesuai dengan penyelesaian yang benar. Sedangkan cara merekonstruksi pengetahuan dilakukan selain dengan memanggil kembali secara pribadi berbagai ingatan terkait konsep-konsep yang sudah pernah dipelajari sebelumnya, juga bertanya pada ahli di bidang materi tersebut, biasanya dia bertanya langsung pada pengajar bukan kepada teman sebaya. Mahasiswa pada level berpikir ini juga memiliki keyakinan yang cukup tinggi dalam menyelesaikan permasalahan yang diberikan dengan memilih metode penyelesaian jawaban yang menurutnya sesuai untuk diterapkan. Mahasiswa mampu menilai diri sendiri sampai sejauh mana mereka memiliki kemampuan dalam memahami berbagai pengetahuan, dengan cara diakhir materi sistem bilangan real mereka menyesuaikan antara tujuan pembelajaran yang telah disampaikan di awal kontrak perkuliahan dengan hasil yang telah dicapai. Sinkronisasi mereka lakukan agar memperoleh kepuasan dalam belajar.

Jika dilihat dari self-judgement, mahasiswa mampu mengingat kembali berbagai materi serta konsep-konsep matematis yang telah dipelajari sebelumnya ketika mulai mempelajari materi sistem bilangan real, diantaranya himpunan, fungsi, dan induksi matematis. Hal ini dilakukan agar tidak memiliki kesulitan berlebih pada proses pembelajaran dibandingkan teman yang lainnya. Tipe pebelajar ini memiliki rasa percaya diri untuk menyalahkan teman lainnya ketika melihat hasil pekerjaan yang dia merasa ada kesalahan, tidak sesuai dengan teori yang dipelajari. Menurut hasil wawancara, rasa percaya diri timbul sehubungan dengan kebiasaan yang dilakukan yaitu mempelajari terlebih dahulu bahan bacaan untuk materi baru, karena akan ditemui konsep dan simbol baru, serta berbagai definisi, teorema, dan aksioma baru. Seperti pada saat mempelajari materi sistem bilangan real, sebelumnya dia sudah membaca terlebih dahulu buku-buku referensi yang disampaikan pada saat kontrak perkuliahan. Keinginan untuk memulai mempelajari sesuatu lebih awal juga menjadi bagian dari motivasi belajar yang timbul dalam dirinya. Motivasi ini 
menjadi salah satu umpan balik terbaik bagi seseorang yang memiliki semangat dalam belajar, sehingga belajar menjadi bermakna dan tujuan pembelajaran berhasil tercapai.

Untuk konteks Learning Targets and Instructional Correctives, mahasiswa di level berpikir relasional abstrak mampu menilai secara mandiri kebenaran dari jawaban yang dia berikan. Mahasiswa pada level ini ketika menemui kebuntuan dalam menjawab atau menyelesaikan suatu permasalahan akan mengosongkan lembar jawabannya kemudian secara langsung bertanya kepada pengajar secara detail mengenai trik menjawab, namun tidak meminta kunci jawabannya. Dia mampu mengoreksi kesalahpahaman dari alur jawaban teman lain karena tipe seperti ini biasanya teliti dan terstruktur dalam menyelesaikan permasalahan. Dia biasanya menjadi tempat teman-teman lain mencari solusi dari soal-soal tipe abstrak yang sering dijumpai pada materi sistem bilangan real. Menurutnya, ketika ia menjadi tempat bagi teman-teman lain bertanya sampai dengan menemui solusi dari berbagai kesulitan yang mereka temui, bukan mengurangi kadar pengetahuan justru memperluas pengetahuannya, sehingga selalu mengulas materi menambah berkembangnya pola pikir dan kemampuan matematis.

Pada mahasiswa dengan fungsi kognitif berpikir matematis rigor level kuantitatif dengan ketelitian memiliki selfmonitoring diantaranya sudah memiliki kesadaran dalam menyelesaikan permasalahan matematis yang diberikan dengan cara yang ia pahami. Mahasiswa mengatur strategi menjawab soal merujuk kepada pengetahuan yang sudah dipelajari sebelumnya, mengambil peran mengatur solusi dengan menghubungkan definisi dan prosedur matematisnya. Kesanggupan dalam menuliskan yang diketahui pada soal, merancang ide penyelesaian masalah yang berpatokan pada komponen yang ditanyakan, dan memilah kesimpulan yang sesuai. Mahasiswa pada fungsi kognitif tipe ini ketika mencari solusi dari permasalahan yang dihadapi, melakukan pengamatan terlenih dahulu sehingga ketika menyimpulkan jawaban fokus dan tepat, namun tidak menghadirkan rincian jawaban secara khusus atau tanpa menggunakan atribut berpikir kritisnya, karena menganggap telah menguasai permasalahan.

Self-judgement dari subjek penelitian dengan level kuantitatif, mahasiswa mampu menghubungkan pengetahuan yang pernah dipahami untuk menyelesaikan permasalahan pada materi sistem bilangan real dengan hasil yang diperoleh. Pebelajar tipe ini menekankan pada kemampuan analisis dan ketelitian pada saat menyimpulkan jawaban, untuk itu dia selalu berusaha mencari informasi dan mengkaji berbagai permasalahan dengan rekan sebaya, dimana kenyamanan dalam belajar menurutnya bisa diperoleh. Tipe ini serius dalam mengikuti pembelajaran, dan bersemangat ketika melakukan diskusi. Ketika diskusipun, ia mampu mengatakan sesuatu yang dianggapnya salah atau menyalahi teori. Namun keadaaan tersebut memang terbatas hanya pada saat diskusi dengan teman sebaya saja, sampai mampu menganalisis secara mendalam. Umpan balik terlihat dari munculnya rasa percaya diri untuk mempelajari materi dan berdiskusi bersama menyelesaikan permasalahan materi sistem bilangan real. Hal ini lebih diperjelas pada saat wawancara yang mendukung kesimpulan ini, mahasiswa sebenarnya memiliki kemampuan dalam memahami materi yang mereka konstruk dari berbagai referensi baik internal maupun eksternal, namun percaya diri itu muncul setelah melalui proses diskusi, dan rasa percaya diri ini harus terus ditumbuhkan dalam dirinya.

Pada bagian Learning Targets and Instructional Correctives, subjek penelitian berusaha untuk mampu meningkatkan kebenaran dari penyelesaian permasalahan 
yang disusun. Ada sisi pebelajar yang memiliki motivasi belajar tinggi untuk selalu melakukan perbaikan dalam setiap proses pembelajaran yang ia lakukan, untuk memperoleh hasil yang lebih baik dari setiap tahapan kegiatan belajar. Hal ini membawa dampak positif dalam menggambarkan fokus pebelajar yang cukup baik dalam mengelola kemampuan kognitifnya yang diseimbangkan dengan afektifnya. Keinginan untuk selalu memperluas pengetahuan yang dimiliki menjadi sebuah usaha dalam meningkatkan keberhasilan faktor nonintelektual, dan upaya dalam membangun pembelajaran bermakna bagi dirinya. Dari hasil wawancara diperoleh informasi bahwa, mahasiswa tipe fungsi kognitif level kuantitatif ini cenderung harus memiliki lingkungan yang mendukung untuk belajar secara berkelompok, karena ia senang untuk saling berbagi informasi dan semangat berkembang dalam lingkungan yang saling mendukung.

Subjek penelitian yang masuk ke dalam fungsi kognitif berpikir matematis rigor level kualitatif, mengenai selfmonitoring ditandai dengan dia melakukan evaluasi terhadap dirinya dengan mampunya menghadirkan berbagai pengetahuan yang ia miliki sebagai materi prasayarat sistem bilangan real untuk kemudian dihubungkan dengan penyelesaian permasalahan. Fokus utama dari subjek tipe ini adalah lebih kepada pelabelan simbol dan lambang kematematikaan serta visualisasi, karena memang berdasarkan hasil kuesioner dan wawancara, ia selalu tertarik untuk menyatakan sesuatu dalam bentuk simbol untuk mempermudah dia dalam merepresentasikan jawaban. Tipe ini tidak terlalu senang menulis kalimat panjang dan detail, karena menurutnya pemisalan dalam simbol sudah mewakili jawaban dari kalimat yang panjang dan sistematis. Karena memang kelemahannya adalah kesulitan menyusun kalimat-kalimat dalam menyatakan suatu jawaban persoalan.
Jika diperhatikan dari self-judgement, tipe kualitatif juga termasuk tipe yang senang berdiskusi dalam penyelesaian permasalahan matematika. Namun tipe ini fokus awalnya lebih kepada mendengarkan terlebih dahulu uraian dari rekan sejawat untuk kemudian dia maknai dan diskusikan dengan pemahamannya. Subjek dengan pemikiran kualitatif, jika menurutnya orang lain salah dalam memaknai sesuatu, dia mampu langsung menyalahkan orang tersebut. Dia akan mengajak diskusi orang yang bersangkutan untuk menunjukkan letak kesalahannya, dengan menunjukkan kelengkapan informasi yang dia miliki berdasarkan materi yang dipelajari dan konsep yang sejalan. Tipe ini menghargai semua pendapat yan disampaikan oleh rekan sebaya dalam forum diskusi, dan menghargai umpan balik berupa penghargaan terhadap simpulan yang dia berikan di akhir dari berbagai teori dan implementasi teori dalam diskusi.

Pada bagian Learning Targets and Instructional Correctives, pemikir tipe kualitatif selalu memiliki semangat dalam meningkatkan potensi dirinya dalam memperbaiki setiap jawaban permasalahan. Jika pemahaman yang disampaikan ada kekeliruan, dia tidak akan berhenti untuk mencari informasi dari berbagai pihak yang dianggap mampu untuk menjelaskan. Mencari berbagai literatur baik eksternal maupun internal selalu menjadi bagian penting dalam mengembangkan dan mnegkonstruksi pengetahuan yang dimiliki. Saling berbagi merupakan salah satu karakter yang baik tergambarkan dalam diri tipe ini, dampaknya mampu mengoreksi kesalahpahaman yang timbul ketika berdiskusi. Berdasarkan kusioner dan wawancara, tipe berpikir kualitatif juga berpandangan bahwa dengan berdiskusi dan saling berbagi dapat memperluas pengetahuan mereka, sehingga tidak hanya dibatasi dengan pemikiran sendiri. 
Fungsi kognitif level berpikir matematis rigor, dengan tiga level berpikir yaitu menunjukkan bahwa semakin banyak pengalaman dengan tingkat kompleksitas yang meningkat, ketekunan intelektual yang tinggi, penyelidikan yang kritis, dan penerimaan terhadap tantangan, serta kualitas pemikiran yang semakin baik maka akan meningkatkan pula kemampuan kognitif mahasiswa yang berorientasi pada tujuan pembelajaran tepat sasaran dengan kualifikasi yang kompleks (Kinard \& Kozulin, 2008). Pemrosesan pemikiran matematis pada berpikir matematis rigor mendorong mahasiswa memiliki keinginan yang kuat, gigih, dan motivasi tinggi dalam belajar sehingga memupuk metakognitif mereka menjadi lebih berkembang. Mahasiswa dapat memonitoring, merencanakan, mengontrol, serta melakukan evaluasi proses dan strategi yang dilakukan melalui instrument metakognitif selfassessment (Syafaah \& Handayani, 2015). Mahasiswa dengan pengetahuan konseptual yang baik, memiliki kemampuan dalam mengevaluasi diri dengan batasan kemampuan masing-masing.

\section{KESIMPULAN DAN SARAN}

Berpikir matematis Rigor berkontribusi pada pengetahuan metakognitif selfassessment mahasiswa. Kualitas pemikiran dari mahasiswa yang memiliki level berpikir matematis Rigor mampu menggiring ketelitian, ketekunan, penyelidikan kritis, dan pencarian kebenaran dalam menyelesaikan rmasalah secara tepat, terstruktur, dan sistematis menjadi sebuah pengalaman langsung dalam proses pembelajaran atau metakognitif. Berbagai bentuk penilaian terhadap diri mahasiswa yang coba diinterpretasikan dari tiga level kognitif berpikir matematis rigor kembali pada kemampuan individu mahasiswa dalam merekonstruksi pengetahuannya yang tercerminkan dalam kemampuan mengukur diri.
Penelitian ini masih terbatas pada pembahasan mengenai metakognitif selfassessment, maka disarankan penelitian ini dapat dilanjutkan untuk menganalisis pengetahuan metakognitif self-management. Kedua pengetahuan tersebut penting untuk mengetahui hubungan antara struktur kognitif yang terbangun selama pembelajaran dengan pengetahuan metakognitifnya. Karena ketika pembahasan lengkap mengenai kognitif dan metakognitif disajikan lengkap, maka dapat memberikan pengetahuan kepada pengajar untuk membuat desain pembelajaran yang sesuai dengan kondisi mahasiswa dan tujuan yang ingin dicapai.

\section{DAFTAR PUSTAKA}

Adadan, E., \& Oner, D. (2018). Examining preservice teachers' reflective thinking skills in the context of web-based portfolios: The role of metacognitive awareness. Australian Journal of Teacher Education, 43(11), 2650. https://doi.org/10.14221/ajte.2018 v43n11.2

Alpi, K. M., \& Evans, J. J. (2019). (2019) Distinguishing case study as a research method from.pdf. 107(January), 1-5.

Aulia, E. T., \& Fitriyani, H. (2019). Implementasi Pendekatan Rigorous Mathematical Thinking (Rmt) Untuk Meningkatkan Kemampuan Pemecahan Masalah Siswa. JOURNAL of MATHEMATICS SCIENCE and EDUCATION, 1(2), 28-42. https://doi.org/10.31540/jmse.v1i2 .300

Catarreira, S. M. V., Lopes, V. G., García, L. M. C., \& González, R. L. (2017). Evaluation of changes in cognitive structures after the learning process in mathematics. 
DOI: https://doi.org/10.24127/ajpm.v10i2.3430

International Journal of Innovation in Science and Mathematics Education, 25(2), 17-33.

Chang, M. M. (2010). Effects of selfmonitoring on web-based language learner's performance and motivation. CALICO Journal, 27(2), 298-310. https://doi.org/10.11139/cj.27.2.2 98-310

Colognesi, S., Piret, C., Demorsy, S., \& Barbier, E. (2020). Teaching writing — with or without metacognition?: An exploratory study of 11-to 12-year-old students writing a book review. International Electronic Journal of Elementary Education, 12(5), 459-470.

https://doi.org/10.26822/iejee.202 0562136

Cresswell, C., \& Speelman, C. P. (2020). Does mathematics training lead to better logical thinking and reasoning? A crosssectional assessment from students to professors. PLOS ONE, $15(7 \quad$ July), 1-21. https://doi.org/10.1371/journal.po ne. 0236153

Fitriyani, H. (2016). Profil Berpikir Matematis Rigor Siswa Smp Dalam Memecahkan Masalah Matematika Ditinjau Dari Perbedaan Kemampuan Matematika. AdMathEdu: Jurnal Ilmiah Pendidikan Matematika, Ilmu Matematika Dan Matematika Terapan, $3(1)$. https://doi.org/10.12928/admathed u.v3i1.4831

Griffin, P. (2019). Assessment for teaching. Assessment for Teaching, 1-320. https://doi.org/10.1017/97811081 16053.002
Hearn, J., \& McMillan, J. H. (2008). Student Self-Assessment: The Key to Stronger Student Motivation and Higher Achievement. Educational Horizons, 87, 40-49.

Hostetler, K., Luo, T., \& Stefaniak, J. E. (2018). Aligning information literacy assessment with metacognitive strategies. Journal of University Teaching and Learning Practice, 15(5).

Hsu, Y. S., Iannone, P., She, H. C., \& Hadwin, A. (2016). Preface for the IJSME Special Issue: Metacognition for Science and Mathematics Learning in Technology-Infused Learning Environments. International Journal of Science and Mathematics Education, 14(2), 243-248.

https://doi.org/10.1007/s10763016-9727-9

Ifenthaler, D., Masduki, I., \& Seel, N. M. (2011). The mystery of cognitive structure and how we can detect it: Tracking the development of cognitive structures over time. Instructional Science, 39(1), 41-61. https://doi.org/10.1007/s11251009-9097-6

Info, A. (2020). Available online at: http://journal.uny.ac.id/index.php/ pythagoras. 15(1), 1-12.

Jaleel, S., \& P., P. (2016). A Study on the Metacognitive Awareness of Secondary School Students. Universal Journal of Educational Research, 4(1), 165-172. https://doi.org/10.13189/ujer.2016 .040121

Kinard, J. T. (2006). Creating rigorous mathematical thinking: A dynamic that drives mathematics and science conceptual 
DOI: https://doi.org/10.24127/ajpm.v10i2.3430

development. Erdélyi Pszichológiai Szemle, Spec Iss2, 251-266.

http://search.ebscohost.com/login. aspx ?direct $=$ true $\& \mathrm{db}=$ psyh $\& A N=$ 2007-07607-007\&site=ehost-live

Kinard, J. T., \& Kozulin, A. (2008). Rigorous mathematical thinking: Conceptual formation in the mathematics classroom. Rigorous Mathematical Thinking: Conceptual Formation in the Mathematics Classroom, 1-209. https://doi.org/10.1017/CBO9780 511814655

Kinard, J. T., \& Kozulin, A. (2015). Review: What Mathematics Should Kids Learn, and How Should They Learn It? Author ( $s$ ): Alan H. Schoenfeld Review by: Alan H. Schoenfeld Published by: University of Illinois Press Stable $U R L$ : http://www.jstor.org/stable/27784 415 Your use of the JS. 122(3), 417-420.

Magsalay, R. J. M., Luna, C. A., \& Tan, R. G. (2019). Comparing the Effect of Explicit Mathematics Instruction with Rigorous Mathematical Thinking Approach and 5E' s Instructional Model on Students , Mathematics Achievement. American Journal Of Educational Research, 7(6), 402-406.

https://doi.org/10.12691/education $-7-6-5$

Navaneedhan, C. G., \& Kamalanabhan, T. J. (2017). What Is Meant by Cognitive Structures? How Does It Influence Teaching -Learning of Psychology? IRA International Journal of Education and Multidisciplinary Studies (ISSN 2455-2526), 7(2), 89. https://doi.org/10.21013/jems.v7.n 2.p5

Nbina, J. B., \& Viko, B. (2010). Effect of instruction in metacognitive self-assessment strategy on chemistry self-efficacy and achievement of senior secondary school students in rivers state, Nigeria. Academic Leadership, $8(4)$.

Nuhfer, E., Cogan, C., Fleischer, S., Gaze, E., \& Wirth, K. (2016). Random Number Simulations Reveal How Random Noise Affects the Measurements and Graphical Portrayals of SelfAssessed Competency. Numeracy, 9(1).

https://doi.org/10.5038/19364660.9.1.4

Purwaningsih, W. I., Studi, P., Matematika, P., \& Purworejo, U. M. (2017). JPSE: Hubungan Kemampuan Metakognitif dan Kemampuan Kognitif Mahasiswa ... 56. November, 56-66.

Rivers, W. P. (2001). Autonomy at all costs: An ethnography of metacognitive self-assessment and self-management among experienced language learners. Modern Language Journal, 85(2), 279-290.

https://doi.org/10.1111/00267902.00109

Sholihah, D. A., \& Mahmudi, A. (2015). Keefektifan Experiential Learning Pembelajaran Matematika MTs Materi Bangun Ruang Sisi Datar. Jurnal Riset Pendidikan Matematika, 2(2), 175. https://doi.org/10.21831/jrpm.v2i2 .7332

Siahaan, M. F. (2017). Students' Perceptions of the Constructivist Instructional Methods in a Teaching and Learning Course. 
DOI: https://doi.org/10.24127/ajpm.v10i2.3430

IJPTE : International Journal of Pedagogy and Teacher Education, 1(2), 155-173. https://doi.org/10.20961/ijpte.v1i2 .15078

Sukiyanto, S. (2020). Munculnya Kesadaran Metakognisi Dalam Menyelesaikan Masalah Matematika. AKSIOMA: Jurnal Program Studi Pendidikan Matematika, 9(1), 126. https://doi.org/10.24127/ajpm.v9i 1.2654

Teks, M., \& Berbahasa, S. (2015). H. K. Syafa'ah $\square, \quad$ L. Handayani.pdf. 4(1).

Veenman, M. V. J. (2012). Definitions, Constituents, and Their Intricate Relation with Cognition. Metacognition in Science Education, Trends in Current Research, 40, 21-36. https://doi.org/10.1007/978-94007-2132-6

Wilkerson-Jerde, M. H., \& Wilensky, U. J. (2011). How do mathematicians learn math?: Resources and acts for constructing and understanding mathematics. Educational Studies in Mathematics, 78(1), 21-43. https://doi.org/10.1007/s10649011-9306-5 